\title{
On the presence of hippuric acid in the blood
}

\section{F. Verdeil \& Ch. Dolfuss}

To cite this article: MM. F. Verdeil \& Ch. Dolfuss (1850) On the presence of hippuric acid in the blood, Philosophical Magazine Series 3, 36:241, 158-158, DOI: 10.1080/14786445008646450

To link to this article: http://dx.doi.org/10.1080/14786445008646450

$$
\text { 册 Published online: } 30 \text { Apr } 2009 .
$$

Submit your article to this journal

Џ Article views: 2

Q View related articles $\sqsubset$ 
as chloride of sodium, chloride of calcium and hydrochlorate of ammonia, dissolves in the chloride of copper, even when the latter is added by drops. Nevertheless in this case, the vibrations occasioned by the formation and precipitation of oxalate of copper should be as much as possible avoided, when it ceases to dissolve in the excess of the salt of copper ; this precipitate is, however, formed after a certain time.

When excess of oxalate of ammonia is poured into chloride of calcium, and a salt of copper is afterwards added, no solution takes place. A precipitate of oxalate of copper is obtained, and a soluble salt of lime remains in the liquor; but if this experiment be made in presence of an excess of hydrochlorate of ammonia, the oxalate of copper does not immediately precipitate, and the solution remains clear for some time.

Oxalate of lime, boiled with soluble salts of silver, lead, cadmium, zinc, nickel, cobalt, strontia and barytes, undergoes double decomposition; so that a soluble salt of lime remains in solution, and the oxalates of these metals are precipitated.

Thus oxalate of lime is decomposed by all the soluble salts of metals capable of forming insoluble oxalates and soluble salts of lime. The decomposition takes place more readily, as the equivalent of the metal which replaces the lime is higher.

The author proposes to extend this inquiry to all the oxalates, and to examine in a more general point of view the action of soluble upon insoluble salts._Comptes Rendus, Novembre 12, 1849.

\section{ON THE PRESENCE OF HIPPURIC ACID IN THE BLOOD. BY MM. F. VERDEIL AND CH. DOLFLSS.}

The authors state in a note to the Academy, that they have discovered hippuric acid in the blood of the ox. 'The blood upon which their experiments were performed was obtained by themselves at the slaughter-house; the experiments were repeated on the blood of many oxen, and hippuric acid was always found to be present. It was perfectly isolated from the blood, and its properties carefully studied. Not having olstained enough of the substance to submit it to an elementary analysis, they satisfied themselves that this substance was similar to the hippuric acid found in the urine of herbivorous animals, by the form of the crystals, as shown by the microscope, their insolubility in cold, and their solubility in hot water, alcohol and æther: this substance fuses by heat, exhaling the characteristic odour of benzoin. The process which the authors employed to separate this substance being connected with their general method employed in the analysis of blood, they propose to describe it when their researches are completed.-Comptes Rendus, Decembre 24, 1849 .

\section{GEOLOGICAL PRIZES.}

The Geological Society of Dublin have offered three prizes, each of the value of Five Pounds in Books, to be awarded for the three 